\title{
Arbuscular Mycorrhizal Fungal Community Structure in Soybean Roots: Comparison between Kanagawa and Hokkaido, Japan
}

\author{
Katsunori Isobe $^{1 *}$, Kohei Maruyama ${ }^{1}$, Singo Nagai ${ }^{1}$, Masao Higo ${ }^{1}$, Tomiya Maekawa ${ }^{1}$, \\ Gaku Mizonobe ${ }^{2}$, Rhae A. Drijber ${ }^{3}$, Ryuichi Ishii ${ }^{1}$ \\ ${ }^{1}$ College of Bioresource Sciences, Nihon University, Fujisawa, Japan \\ ${ }^{2}$ Hokkaido College, Senshu University, Bibai, Japan \\ ${ }^{3}$ Department of Agronomy and Horticulture, University of Nebraska-Lincoln, Lincoln, USA \\ E-mail: ${ }^{*}$ isobe64@brs.nihon-u.ac.jp \\ Received November 5, 2011; revised November 21, 2011; accepted December 10, 2011
}

\begin{abstract}
The objectives of this study were to determine arbuscular mycorrhizal fungi (AMF) community structure in colonized roots of soybean cultivated from Kanagawa and Hokkaido in Japan and to relate the community structure to environmental conditions, which included soil type, preceding crops, and soil chemical properties. The average number of AMF OTU (operational taxonomic unit) colonizing soybean roots collected from Kanagawa and Hokkaido was 11.2 and 5.8, respectively, a significant difference. Moreover, AMF from the family Gigasporasera was not identified in soybean roots collected from Hokkaido, suggesting that AMF in the family Gigasporasea is absent or rare in the soybean fields of sampled in Hokkaido. We postulate that the soil type, preceding crops or soil chemical properties are not the underlying factor differentiating AMF community structure colonizing in soybean roots between Kanagawa and Hokkaido. Instead we conclude that temperature and phosphate absorption coefficient are the determining factors of AMF OTU in this study.
\end{abstract}

Keywords: AM Fungi, Colonization, Community Structure, Soybean

\section{Introduction}

Arbuscular mycorrhizal fungi (AMF) are one of the most important soil microorganisms, forming symbiotic associations with terrestrial plant roots of most species. It is well known that AMF improve the uptake of immobile mineral nutrients such as phosphate, thereby benefiting plant growth [1-3]. The extent of such benefit varies with the soil environment, particularly available P content and soil moisture. However, one of the most important factors in promoting host plant growth is an increase in rate of colonization with AMF, which itself is strongly influenced by AMF density in the soil. Therefore, to effectively use AMF for crop cultivation, it is extremely important to clarify the density of AMF in upland field soil. Isobe et al. [4] reported that AMF spore density was higher in the soils with a higher phosphate absorption coefficient, and negatively correlated with the available phosphorus content. Moreover, the AMF colonization rate of soybean in regions of Japan was largely influ- enced by soil chemical properties [4]. AMF colonization rate was positively correlated with AMF spore density, and negatively with available soil phosphorus. In generally, AMF spore density is also assumed to be lower in acidic and alkaline soils $[5,6]$. From these facts, we considered that the AMF spore density in field soil affected by soil condition, for example soil chemical property.

More than 150 AMF species have been described based on their spore morphology [7]. The individual AMF species may differ in their growth response to different plant $[8,9]$. These functional differences underlie the importance of clarifying which AMF species colonize specific crops [10]. Consequently, the presence or absence of AMF, as well as overall AMF community structure or diversity has been shown to affect plant productivity in agricultural ecosystems [11-13]. High AMF diversity may result in more agricultural production provided that the co-existing AMF species can benefit the crop under various stress conditions [14]. However, low diversity is not necessarily disadvantageous if the few 
AMF species present are beneficial under a broad range of agricultural and edaphic conditions [15].

Recently, molecular methods have been used in studies of AMF community structure in roots and soil $[16,17]$. Consequently, there are several reports of AMF community structure in field soils and crop roots based on molecular approaches [18-22]. AMF community structure in soils and/or roots has been shown to differ between geographic regions [23] and is responsive to various factors including soil type, environmental conditions and host plans [2,24-26]. Isobe et al. [4] reported that the colonization rate of the soybean roots at Hokkaido were lower than that of root samples collected from Kanagawa. But, in this paper, AMF community structure in soybean roots collected from Hokkaido and Kanagawa did not investigate. The objectives of this study were to investigate arbuscular mycorrhizal fungi (AMF) community structure in colonized roots of soybean cultivated from Kanagawa and Hokkaido in Japan and to relate the community structure to environmental conditions, which included soil type, preceding crops, and soil chemical properties.

\section{Material and Methods}

\subsection{Sampling Site and Sampling Method}

Soybean (Glycine max L. Merr.) roots and rhizosphere soils were sampled in August 2006 from six sites in Kanagawa and four sites in Hokkaido, Japan. Each sampling site in Kanagawa and Hokkaido was located within a $40 \mathrm{~km}$ radius from Nihon University and Senshu University, respectively. Kanagawa (Fujisawa-city) and Hokkaido (Bibai-city) have a temperate climate with a mean annual temperature of 15.9 and $7.1 \mathrm{C}$, and 1448 and 1156 $\mathrm{mm}$ annual precipitation, respectively. All sites are less than $100 \mathrm{~m}$ in altitude. The size of each field was different at each location, the smallest field was about $100 \mathrm{~m}^{2}$ (No. 6) and the biggest field was about $5000 \mathrm{~m}^{2}$ (No. 9). Roots and soils were collected from the center of each field. Roots were sampled from 15 randomly selected plants and rhizosphere soil was collected within the circumference of the sampled roots, $15 \mathrm{~cm}$ in depth $\times 20$ $\mathrm{cm}$ in diameter. Roots were divided into two subsamples (about 100 roots of $1.5 \mathrm{~cm}$ length) and used for measurement of AMF colonization rate and DNA extraction. The variety of soybean was Enrei in Kanagawa, and Tsurumusume or Iwaiguro in Hokkaido, and the sampling time was at the flowering stage of soybean. Table 1 shows the sowing date of soybean, sampling date, variety of soybean, soil group and preceding crops.

\subsection{Analysis of Soil Chemical Property and AMF Spore Number}

A portion of the soil sample was air-dried for measure- ment of chemical properties and the remainder was used to determine the number of AMF spores. The $\mathrm{pH}\left(\mathrm{H}_{2} \mathrm{O}\right)$, phosphate absorption coefficient and available phosphate were measured by the glass electrode method, the ammonium phosphate method, and Bray 2 method, respectively. AMF spores were recovered by wet sieving through a $53 \mu \mathrm{m}$ mesh followed by sucrose density gradient centrifugation, and then were counted under a microscope. Spore morphology was also recorded.

\subsection{Analysis of AMF Colonization Rate in Soybean Root}

Soybean roots were stained with trypan blue and measured for AMF colonization rate by a grid crossing-point method and the presence of hyphae, dendrophyses, and cystidia were noted [27]. The size of grid was $5 \mathrm{~mm}$ quarters; the count number of the crossing of grid and root in one plant was lowest 200.

\subsection{Analysis of AMF Community Structure}

\subsubsection{DNA Extraction from the Roots}

Root samples were pulverized in a $2.0-\mathrm{mL}$ tube containing five $2.0 \mathrm{~mm}$ zirconium balls using an MS-100 microhomogenizing system (Tomy Digital Biology Co., Ltd., Tokyo, Japan) at $4000 \mathrm{rpm}$ for $1 \mathrm{~min}$. The samples were homogenized again at $4000 \mathrm{rpm}$ for $1 \mathrm{~min}$ after the addition of $500 \mu \mathrm{L}$ of $2 \times$ hexadecyltrimethylammonium bromide (CTAB) solution [2\% CTAB, $0.1 \mathrm{M}$ Tris- $\mathrm{HCl}$ (pH 8.0), $20 \mathrm{mM}$ EDTA, $1.4 \mathrm{M} \mathrm{NaCl}$, and $0.5 \% \beta$-mercaptoethanol]. The homogenate was incubated in a block heater at $65^{\circ} \mathrm{C}$ for $1 \mathrm{~h}$. After adding $500 \mu \mathrm{L}$ of chloroform and isoamyl alcohol mixture $(24: 1, \mathrm{v}: \mathrm{v})$, each tube was vortexed and then centrifuged at $20,400 \times \mathrm{g}$ for $7 \mathrm{~min}$. The supernatant was transferred to $1.5-\mathrm{mL}$ tube, and the DNA was precipitated by adding an equal volume of isopropyl alcohol then stored at $-30^{\circ} \mathrm{C}$ for $10 \mathrm{~min}$. After centrifugation at $5,800 \times \mathrm{g}$ at $4^{\circ} \mathrm{C}$ for $10 \mathrm{~min}$, the DNA pellet was washed with $80 \%$ ethanol and resuspended in $120 \mu \mathrm{L}$ of TE buffer solution [10 mM Tris- $\mathrm{HCl}(\mathrm{pH} 8.0)$ and $1 \mathrm{mM}$ EDTA], and stored at $-30^{\circ} \mathrm{C}$ before analysis.

\subsubsection{Molecular Analysis}

A portion of the LSU rDNA region of fungal DNA was amplified using a nested PCR method [28]. The DNA samples extracted from plant roots were diluted 20-fold and used as PCR templates. Primers of LR1 and FLR2, which are specific to fungi, were used to amplify the 5'end of the LSU rDNA region [29]. The method and PCR conditions were the same as those described by Wu et al. [30]. PCR was performed in $10-\mu \mathrm{L}$ reaction mixtures containing $1 \mu \mathrm{L}$ template DNA, $1 \mu \mathrm{L}$ of $10 \times$ PCR buffer, 
$0.2 \mathrm{mM}$ of each dNTP, $0.3 \mu \mathrm{M}$ of each primer, and 0.25 U of TaKaRa Taq DNA polymerase (Takara Shuzo Co., Tokyo, Japan) using a thermocycler (GeneAmp 9700, Applied Biosystems). The PCR protocol was 1 cycle at $94^{\circ} \mathrm{C}$ for $1 \mathrm{~min} ; 29$ cycles at $94^{\circ} \mathrm{C}$ for $30 \mathrm{~s}, 54^{\circ} \mathrm{C}$ for $30 \mathrm{~s}$, and $72^{\circ} \mathrm{C}$ for $1 \mathrm{~min}$; and 1 cycle at $94^{\circ} \mathrm{C}$ for $30 \mathrm{~s}, 54^{\circ} \mathrm{C}$ for $30 \mathrm{~s}$, and $72^{\circ} \mathrm{C}$ for $10 \mathrm{~min}$.

The first-round PCR products were diluted 100-fold and used as templates for the second-round PCR using nested primers FLR3 and FLR4 under the same PCR conditions as described above [28,31]. The FLR3 primer was labeled with Texas Red to generate 5'-end-labeled products. The second-round PCR products $\left(\mathrm{FLR}_{3-4}\right)$ were separated by electrophoresis and analyzed for fragment length polymorphism following Wu et al. [30]. The PCR products $\left(\mathrm{FLR}_{3-4}\right)$ were diluted appropriately with $\mathrm{TE}$ buffer, denatured at $95^{\circ} \mathrm{C}$ for $5 \mathrm{~min}$, and loaded on $6 \%$ sequencing gels (Long Ranger; Cambrex Bio Science Rockland Inc., Rockland, USA) made with $1.2 \times$ TBE [0.1 M Tris, $3.0 \mathrm{mM}$ EDTA, and $0.1 \mathrm{M}$ boric acid] containing 6.1 $\mathrm{M}$ urea. The samples were subjected to electrophoresis in $0.6 \times$ TBE on a DNA sequencing apparatus (SQ-5500; Hitachi Electronics Engineering Co., Tokyo, Japan). DNA size standards were loaded at every tenth lane on the gel. The length of each fragment was estimated from the size standards using FRAGLYS 3.0 software (Hitachi Electronics).

The second-round $\mathrm{FLR}_{3-4}$ PCR products were re-amplified from the diluted first-round PCR products (LR1 to FLR2) and subcloned into pT7Blue using the Perfectly Blunt Cloning Kit (Novagen Inc., Madison, WI) following the manufacturer's instructions. Colonies were randomly selected. The plasmid DNA was extracted from transformed E. coli cells for $5 \mathrm{~min}$ at $94^{\circ} \mathrm{C}$ and used as a template for PCR using the PCR conditions described above. PCR was conducted using M13 forward and reverse primers (RPN 2337 and RPN 2338; Amersham International plc., Buckinghamshire, England), and the products were electrophoresed on agarose gels to confirm insertion of the FLR3-4 PCR fragments into the plasmids. To sequence the inserts, a part of plasmids containing FLR3-4 fragments were sequenced in both directions using Texas Red M13 forward or T7 primers by cycle sequencing using ThermoSequenase Pre-Mixed Cycle Sequencing Kits (RPN 2444, Amersham International) following the manufacturer's instructions and were analyzed on a DNA sequencer (Hitachi Electronics). The other plasmids were also sequenced in both directions using M13 forward or M13 Reverse primers by cycle sequencing using a BigDye Terminator v3.1/1.1 Cycle Sequencing Kit (Applied Biosystems) following the manufacturer's instructions and were analyzed on a DNA sequencer (ABI 3100, Applied Biosystems).

\subsubsection{Data Analysis}

Species of AMF were inferred from sequence homologies with sequences recorded in the DNA Data Bank of Japan (DDBJ, http://www.ddbj.nig.ac.jp/). Multiple alignments and neighbor-joining phylogenic trees were constructed using MEGA 4 [32]; Mortierella verticillata (accession no. AF157199) were used as out-groups.

\subsection{Statistical Analysis}

A one-way analysis of variance (ANOVA) followed by Tukey's multiple means test was done to compare soil $\mathrm{pH}$, phosphorus absorption coefficient, available phosphate content, AMF spore density, and AMF colonization rate among sites at $\mathrm{P}<0.05$. Significant differences in spore density, AMF colonization rate and number of AMF OTU between Kanagawa and Hokkaido was determined by t-test. The coefficient of correlation between AMF spore density or colonization rate and soil chemical properties $(\mathrm{pH}$, phosphorus absorption coefficient, available phosphate content) or AMF colonization rate were also measured. Correlation analysis was done using Kaleida Graph ver.4.0 software.

\section{Results}

The $\mathrm{pH}$ of the collected soil ranged from 5.4 (No. 9) to 7.4 (No. 4). There was a significant difference in $\mathrm{pH}$ with sampling site. The soil samples collected at sites 3, 4 and 5 had the highest $\mathrm{pH}$, and the samples collected at sites 9 and 10 had a lower $\mathrm{pH}$ than the other samples. The soil samples collected at sites 3, 4, 5 and 6 had the highest $\mathrm{pH}$, and the samples collected at 9 and 10 had a lower $\mathrm{pH}$ than the other samples. The phosphorus absorption coefficient of the collected soil ranged from 460 (No. 7) to 2270 (No. 5). There was a significant difference in phosphorus absorption coefficient with sampling site. The soil samples collected at sites 5 and 6 had the highest phosphorus absorption coefficient. The available phosphorus content ranged from $0.42 \mathrm{~g} \mathrm{~kg}-1$ (No. 8) to $0.07 \mathrm{~g}$ kg-1 (No. 5) and there was a significant difference in available phosphorus content with sampling site. The soil sample collected at site 8 had the highest available phosphorus content, and the sample collected at site 5 had lower available phosphorus content than the other samples. The AMF spore density differed with the sampling site. The spore density was highest at sites 5 and 6 , and lowest at site 10. There was significant difference in spore density between sites 5 and 6 and sites 1, 2, 7, 8 and 10 . The colonization rate of soybean roots also varied greatly among sites. The root samples at site 5 had the highest colonization rate followed by those from sites 6 and 8 . The colonization rate of the roots at site No. 3 
was lower than that of root samples collected from sites 1, 5-9 and 10 (Table 2).

The phylogenetic tree (Figure 1) contains AMF species/clones from the Glomaceae, Acaulosporaceae, Gigasporaceae, Diversisporaceae and Paraglomeraceae. LSU rDNA gene sequences were partitioned into 25 clusters, potentially yielding 25 OTU. The sequence identity within the clusters ranged from $97.5 \%$ to $100 \%$. Among the 25 OTU, 14 belonged to the Glomaceae, five to Gigasporaceae, four to Acaulosporaceae, one to Diversisporaceae and one to Paraglomeraceae. The AMF population was heavily dominated by the Glomaceae. And OTU of Glo 1 belonged to the Glomaceae colonized soybean roots of all sampling sites. OTU of Acaulosporaceae only colonized soybean roots collected from site No. 1, 2 in Kanagawa and site No. 9 in Hokkaido. And OTU of Diversisporaceae only colonized soybean roots collected from site No. 1 in Kanagawa, and OTU of Paraglomeraceae only colonized soybean roots collected from site No. 4 in Kanagawa and No. 9 in Hokkaido. AMF of Gigasporaceae (Gig 1-3, Scu 1, 2) did not colonized soybean roots collected from Hokkaido (No. 7-10). The number of AMF OTUs were different among sampling sites. In soybean roots collected from Kanagawa, the number of AMF OTUs ranged from eight (No. 4) to 15 (No. 6). Four to seven OTUs were found in soybean roots collected from Hokkaido (Figure 1, Table 3).

Table 4 shows the average AMF spore density in the soil, AMF colonization rate, and number of AMF OTUs colonizing soybean roots collected from Kanagawa (No. 1-6) and Hokkaido (No. 7-10). The average AMF spore density collected from Kanagawa and Hokkaido was $4.5 / \mathrm{g}$ and $3.3 / \mathrm{g}$, respectively. The average AMF colonization rate collected from Kanagawa and Hokkaido was $13.0 \%$ and $15.0 \%$, respectively. And the average number of AMF OTU in root collected from Kanagawa and Hokkaido was 11.2 and 5.8, respectively. There were no significant differences in spore density and colonization rate between Kanagawa and Hokkaido. However, there was a singnificant difference $(p=0.01)$ in the number of
AMF OTUs colonizing soybean roots between Kanagawa and Hokkaido. The average number of AMF OTUs colonizing soybean roots collected from Kanagawa and Hokkaido was 11.2 and 5.8, respectively. Table 5 shows the correlation coefficient between AMF spore density in field soil, AMF colonization rate and soil chemical properties $(\mathrm{pH}$, phosphate absorption coefficient and available phosphorus content). AMF spore density was positively correlated $(\mathrm{r}=0.751 ; \mathrm{p}=0.05)$ with the phosphate absorption coefficient. However, the correlation coefficients of the AMF spore density with soil $\mathrm{pH}$, available phosphorus content and AMF colonization rate were not significant. And the correlation coefficients of the AMF colonization rate with soil $\mathrm{pH}$, phosphate absorption coefficient and available phosphorus content were not significant, too.

\section{Discussion}

\subsection{AMF Spore Density and Colonization Rate among Regions in Kanagawa and Hokkaido}

We found that AMF spore density in soybean fields and AMF colonization rate of soybean roots did not differ between Kanagawa and Hokkaido (Table 4). The same results were obtained by Isobe et al. [5], for other regions of Japan. In the present study, AMF spore density and colonization rate varied remarkably with sampling sate; however, a highly positive correlation $\left(\mathrm{r}=0.751^{*}\right)$ was observed between AMF spore density and the phosphate absorption coefficient of the soil (Table 5) in agreement with previous reports [4]. This suggests a higher abundance of AMF spores in soils where the potential for $\mathrm{P}$ fixation is high, e.g. volcanic ash soils. This is supported by comparatively higher AMF spore density in andosols (sites 5 and 6) and volcanogenous regosols (sites 8 and 9) (Tables 1, 2). In soils with the high phosphate adsorption, AMF play an important role in acquiring P for the crop.

Isobe et al. [4] reported that AMF colonization rate was negatively correlated with the available phosphorus

Table 1. Soybean sowing date, sampling date, variety of soybean, soil group and preceding crop of each sampling site.

\begin{tabular}{|c|c|c|c|c|c|c|}
\hline Prefecture & Site No. & Sowing date $(\mathrm{M} / \mathrm{D} / \mathrm{Y})$ & Sampling date $(\mathrm{M} / \mathrm{D} / \mathrm{Y})$ & Variety of soybean & Soil group & $\begin{array}{c}\text { Preceding crop } \\
\text { (Host plant of AMF or Non) }\end{array}$ \\
\hline \multirow[t]{5}{*}{ Kanagawa } & 1 & Jun./02/2006 & Aug./08/2006 & Enrei & Brown lowland soil & Groundnut (Host) \\
\hline & 3 & Jun./02/2006 & Aug./08/2006 & Enrei & Brown lowland soil & Saltwort (Non) \\
\hline & 4 & Jun./02/2006 & Aug./08/2006 & Enrei & Gray lowland soil & Bare ground \\
\hline & 5 & Jun./01/2006 & Aug./07/2006 & Enrei & Andosol & Groundnut (Host) \\
\hline & 6 & Jun./01/2006 & Aug./07/2006 & Enrei & Andosol & Sweet potato (Host) \\
\hline \multirow[t]{4}{*}{ Hokkaido } & 7 & May/18/2006 & Aug./10/2006 & Tsurumusume & Gray lowland soil & Soybean (Host) \\
\hline & 8 & May/17/2006 & Aug./10/2006 & Iwaiguro & Volcanogenous regosol & Sugar beet (Non) \\
\hline & 9 & May/17/2006 & Aug./10/2006 & Iwaiguro & Volcanogenous regosol & Wheat (Host) \\
\hline & 10 & Jul./11/2006 & Aug./16/2006 & Iwaiguro & Pseudogley soil & Squash (Host) \\
\hline
\end{tabular}


content in the soil in agreement with several other studies $[1,2]$. In this study, a negative correlation $(-0.300)$ was also observed between AMF colonization rate and the amount of available phosphorus in the soil (Table 5). However, this correlation was not statistically significant. From this we conclude that the effects of the available phosphorus in the soil on AMF colonization are smaller than the effect of the phosphate adsorption coefficient of the soil on the AMF spore density.

\subsection{Genus Glomus Ubiquitous among Soybean Roots of Kanagawa and Hokkaido}

In general, the proportion of the AMF of genus Glomus

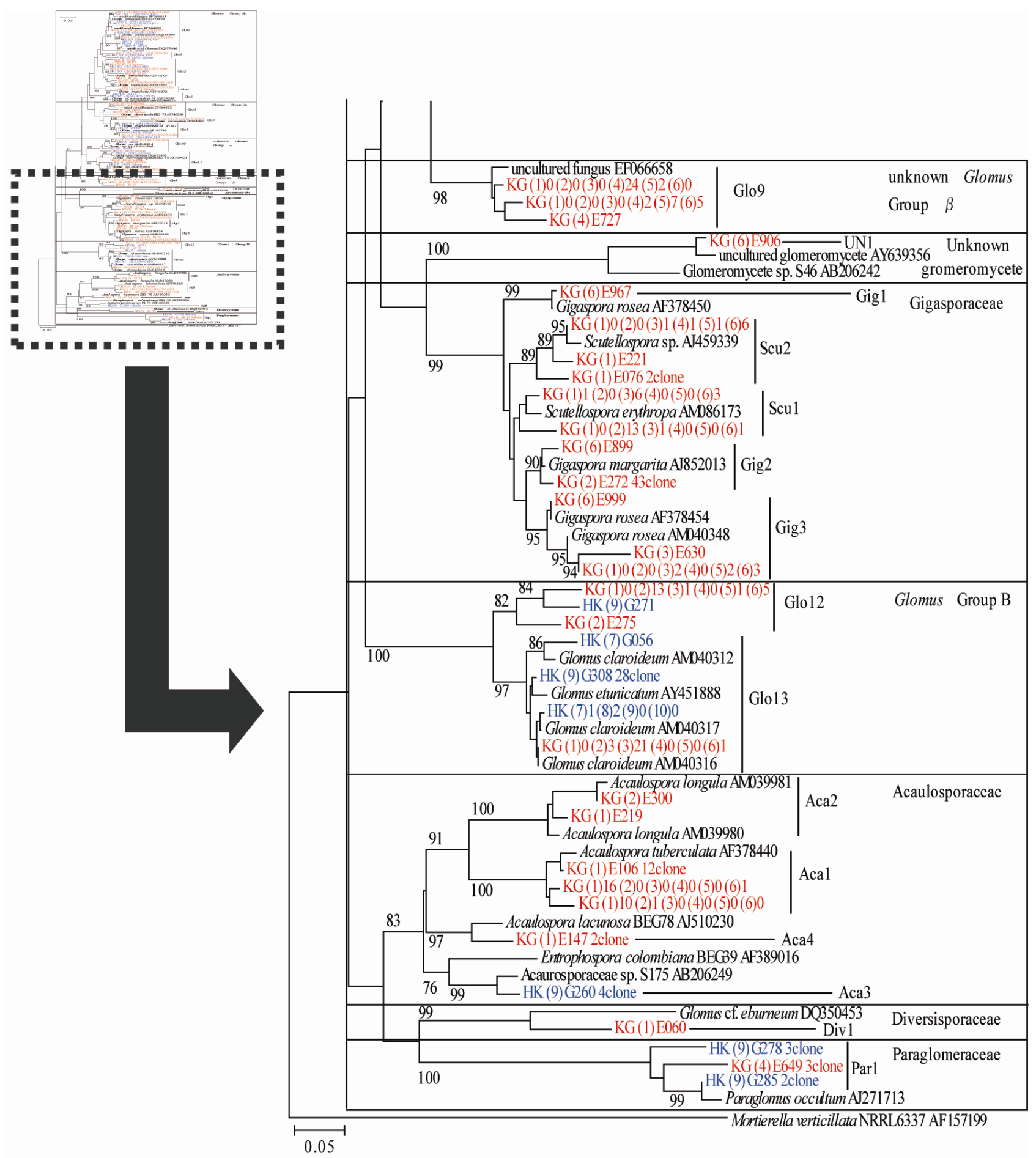



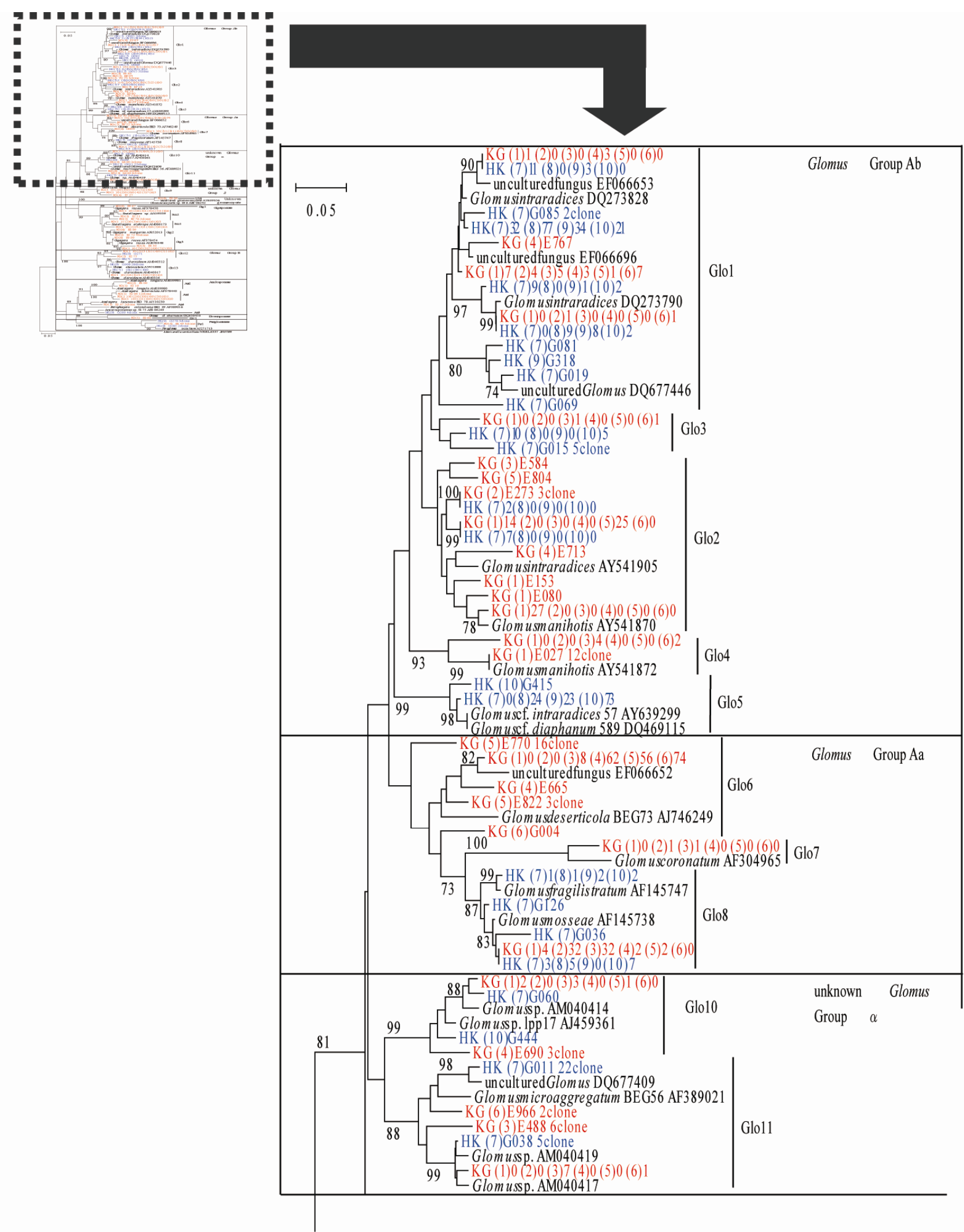

Figure 1. Neighbour-joining phylogenetic tree of partial LSU rDNA sequences from AMF colonizing in soybean root collected from Kanagawa and Hokkaido. KG: Kanagawa, HK:Hokkaido. 
Table 2. Soil pH, phosphorus absorption coefficient, available phosphate content and AMF spore density of sampling soil and AMF colonization rate of soybean roots collected from each sampling site.

\begin{tabular}{|c|c|c|c|c|c|c|}
\hline Prefecture & Site No. & $\mathrm{pH}\left(\mathrm{H}_{2} \mathrm{O}\right)$ & $\mathrm{P}$ absorption coefficient & Available-P (g/kg) & AMF spore density (/g dry soil) & AMF colonization rate $(\%)$ \\
\hline \multirow[t]{5}{*}{ Kanagawa } & 1 & $6.6 b^{*}$ & $740 \mathrm{~d}$ & $0.28 \mathrm{~b}$ & $1.7 \mathrm{~cd}$ & $16.2 \mathrm{bc}$ \\
\hline & 2 & $6.4 b$ & $970 \mathrm{c}$ & $0.21 b c$ & $1.8 \mathrm{~cd}$ & $5.2 \mathrm{ef}$ \\
\hline & 4 & $7.4 \mathrm{a}$ & $1290 \mathrm{~b}$ & $0.22 b$ & $5.4 \mathrm{ab}$ & $4.2 \mathrm{ef}$ \\
\hline & 5 & $7.2 \mathrm{a}$ & $2270 \mathrm{a}$ & $0.07 \mathrm{~d}$ & $7.0 \mathrm{a}$ & $30.4 \mathrm{a}$ \\
\hline & 6 & $6.8 \mathrm{ab}$ & $1830 \mathrm{a}$ & $0.14 \mathrm{c}$ & $6.8 \mathrm{a}$ & $20.1 b$ \\
\hline \multirow{4}{*}{ Hokkaido } & 7 & $6.2 \mathrm{~b}$ & $460 \mathrm{e}$ & $0.22 b$ & $3.0 \mathrm{bcd}$ & $12.8 \mathrm{~cd}$ \\
\hline & 8 & $6.4 \mathrm{~b}$ & $1320 b$ & $0.42 \mathrm{a}$ & $3.8 \mathrm{bcd}$ & $18.8 \mathrm{~b}$ \\
\hline & 9 & $5.4 \mathrm{c}$ & $520 \mathrm{e}$ & $0.15 \mathrm{c}$ & $5.1 \mathrm{ab}$ & $8.2 \mathrm{de}$ \\
\hline & 10 & $5.6 \mathrm{c}$ & $530 \mathrm{e}$ & $0.16 \mathrm{c}$ & $1.3 \mathrm{~d}$ & $20.5 b$ \\
\hline
\end{tabular}

*: Means followed by the same letters are not significantly different at 0.05 level according to Tukey’s multiple range test.

Table 3. AMF OTU colonized in soybean root.

\begin{tabular}{|c|c|c|c|c|c|c|c|c|c|c|}
\hline \multirow{2}{*}{ OTU } & \multicolumn{5}{|c|}{ Kanagawa } & \multicolumn{4}{|c|}{ Hokkaido } & \multirow[b]{2}{*}{10} \\
\hline & 1 & 2 & 3 & 4 & 5 & 6 & 7 & 8 & 9 & \\
\hline Glo1 & $\bullet$ & $\bullet$ & $\bullet$ & $\bullet$ & $\bullet$ & $\bullet$ & $\bullet$ & $\bullet$ & $\bullet$ & $\bullet$ \\
\hline 2 & $\bullet$ & $\bullet$ & $\bullet$ & $\bullet$ & $\bullet$ & & $\bullet$ & & & \\
\hline 3 & & & $\bullet$ & & & $\bullet$ & $\bullet$ & & & $\bullet$ \\
\hline 4 & $\bullet$ & & $\bullet$ & & & $\bullet$ & & & & \\
\hline 5 & & & & & & & & $\bullet$ & $\bullet$ & $\bullet$ \\
\hline 6 & & & $\bullet$ & $\bullet$ & $\bullet$ & $\bullet$ & & & & \\
\hline 7 & & $\bullet$ & $\bullet$ & & & & & & & \\
\hline 8 & $\bullet$ & $\bullet$ & $\bullet$ & $\bullet$ & $\bullet$ & & $\bullet$ & $\bullet$ & $\bullet$ & $\bullet$ \\
\hline 9 & & & & $\bullet$ & $\bullet$ & $\bullet$ & & & & \\
\hline 10 & $\bullet$ & & $\bullet$ & $\bullet$ & $\bullet$ & & $\bullet$ & & & $\bullet$ \\
\hline 11 & & & $\bullet$ & & & $\bullet$ & $\bullet$ & & & \\
\hline 12 & & $\bullet$ & $\bullet$ & & $\bullet$ & $\bullet$ & & & $\bullet$ & \\
\hline 13 & & $\bullet$ & $\bullet$ & & & $\bullet$ & $\bullet$ & $\bullet$ & $\bullet$ & \\
\hline Gig1 & & & & & & $\bullet$ & & & & \\
\hline 2 & & $\bullet$ & & & & $\bullet$ & & & & \\
\hline 3 & & & $\bullet$ & & $\bullet$ & $\bullet$ & & & & \\
\hline Scul & $\bullet$ & $\bullet$ & $\bullet$ & & & $\bullet$ & & & & \\
\hline 2 & $\bullet$ & & $\bullet$ & $\bullet$ & $\bullet$ & $\bullet$ & & & & \\
\hline Acal & $\bullet$ & $\bullet$ & & & & $\bullet$ & & & & \\
\hline 2 & $\bullet$ & $\bullet$ & & & & & & & & \\
\hline 3 & & & & & & & & & $\bullet$ & \\
\hline 4 & $\bullet$ & & & & & & & & & \\
\hline Div1 & $\bullet$ & & & & & & & & & \\
\hline Pra1 & & & & $\bullet$ & & & & & $\bullet$ & \\
\hline Un-known & & & & & & $\bullet$ & & & & \\
\hline Number of OUT ${ }^{*}$ & 11 & 10 & 14 & 8 & 9 & 15 & 7 & 4 & 7 & 5 \\
\hline
\end{tabular}

*: LSU rDNA gene sequences were partitioned into 25 clusters, potentially yielding 25 OTU (Figure 1). The sequence identity within the clusters ranged from $97.5 \%$ to $100 \%$.

Table 4. t-test of spore number, colonization rate and number of OTU between Kanagawa and Hokkaido.

\begin{tabular}{cccc}
\hline Prefecture & $\begin{array}{c}\text { Spore density } \\
\text { (/g dry soil) }\end{array}$ & $\begin{array}{c}\text { Colonization rate } \\
(\%)\end{array}$ & $\begin{array}{c}\text { Number of AMF } \\
\text { OTU in root }\end{array}$ \\
\hline Kanagawa & $4.5 \pm 1.0$ & $13.0 \pm 4.5$ & $11.2 \pm 1.1$ \\
Hokkaido & $3.3 \pm 0.8$ & $15.0 \pm 2.8$ & $5.8 \pm 0.8$ \\
Significance & ns & ns & $* *$ \\
\hline
\end{tabular}

ns: no significance between Kanagawa and Hokkaido by t-test. ${ }^{* *}: 1 \%$ level of significance between Kanagawa and Hokkaido by t-test.

is higher in agroecosystems than natural ecosystems [33-
36]. In the present study, AMF of genus Glomus were the most abundant colonizer of soybean roots in either region or site (Table 3). The genus Glomus is known to be very adaptable to temperature and soil $\mathrm{pH}$ [37]. Futhermore, Tarafdar and Praveen-Kumar [38] also considered Glomus to be the most abundant of all AMF genera in arid environments. Therefore, Glomus dominates many soil environments [14,23,37-40]. However, all Glomus OTUs did not colonize soybean roots equally Glo1 was found in soybean roots collected from all sites. Glo2, Glo8, and Glo13 also colonized soybean roots over most regions and sites (Table 3). We consider that AMF OTUs Glo1, Glo2, Glo8, and Glo13 are universal to soybean plants of Kanagawa and Hokkaido. In contract, Glo 4 only colonized soybean roots from Kanagawa, and Glo5 colonized soybean roots from Hokkaido (Table 3). We considered these OTUs to be regionally specific.

\subsection{Absence of Gigasporasea in Soybean Roots from Hokkaido}

Lekberg et al. [41] reported that soil type was the one of most important factors to affect AMF community structure. But, soils of different types were not dominated by unique or specific AMF (Table 3). AMF of the family Gigasporasera were absent from soybean roots collected from Hokkaido (Table 3, Figure 1). Thus, AMF in the family Gigasporasea either does not exist or rarely exists in the soybean fields of Hokkaido. Schenck and Smith [42] reported root colonization by Glomus ambisporum was singnificantly greater than that of Gigaspora margarita at $24^{\circ} \mathrm{C}$; however, percent root colonization was similar for all AMF species at $30^{\circ} \mathrm{C}$. Moreover, spore production by $\mathrm{AMF}$ in the family Gigasporasea was reduced under cold temperatures $\left(18^{\circ} \mathrm{C}\right)$ more than for other families [42]. Hokkaido is a colder region in Japan and the annual mean temperature is about $10^{\circ} \mathrm{C}$ lower than that of Kanagawa. Thus, colder temperatures many be responsible for the absence of Gigasporasea in soy- 
Table 5. Coefficient of correlation between AMF spore density or AMF colonization rate and soil pH, phosphate absorption coefficient, available phosphate content and AMF colonization rate.

\begin{tabular}{ccccc}
\hline & $\mathrm{pH}$ & $\mathrm{P}$ absorption coefficient & Available-P & AMF colonization rate \\
\hline AMF spore density & 0.478 & $0.751^{*}$ & -0.421 & 0.242 \\
AMF colonization rate & -0.024 & 0.385 & -0.300 & - \\
\hline
\end{tabular}

*: $5 \%$ level of significance between Kanagawa and Hokkaido by t-test.

bean roots collected from Hokkaido.

\subsection{AMF Biodiversity in Soybean Roots between Regions in Japan}

The number of AMF OTUs colonizing soybean roots collected from Hokkaido was lower $(p=0.01)$ than that from Kanagawa (Tables 3, 4). This finding indicates that the diversity of AMF colonizing soybean roots collected from Hokkaido is lower than that of Kanagawa. The community structure of AMF in the soil varies with the plant species and cropping system $[13,43]$. And the introduction of AMF non-host crops into a crop rotation has been shown to decrease AMF biodiversity in soil. In this experiment, non-host crops and host crops of AMF were used prior to soybean cultivation in both Kanagawa and Hokkaido. But, the results of this experiment was that the number of AMF OTU colonizing soybean roots collected from Hokkaido was considerably lower than roots collected from Kanagawa (Tables 3, 4). It should be concluded that the AMF biodiversity in soybean roots was more affected by region (Kanagawa or Hokkaido) than by preceding crop.

\section{References}

[1] A. Mohammad, B. Mitra and A. G. Khan, "Effects of Sheared-Root Inoculum of Glomus intraradices on Wheat Grown at Different Phosphorus Levels in the Field," Agriculture, Ecosystems \& Environment, Vol. 103, No. 1, 2004, pp. 245-249. doi:10.1016/j.agee.2003.09.017

[2] Y. Lekberg and R. T. Koide, "Arbusclar Mycorrhial Fungi, Rhizobia, Available Soil $\mathrm{P}$ and Nodulation of Groundnut (Arachis hypogaea) in Zimbabwe," Agriculture, Ecosystems \& Environment, Vol. 110, No. 3-4, 2005, pp. 143-148. doi:10.1016/j.agee.2005.03.011

[3] G. S. Smith and R. W. Roncadori, "Response of Three Vesicular-Arbuscular Mycorrhizal Fungi at Four Soil Temperatures and Their Effects on Cotton Growth," New Phytologist, Vol. 104, No. 1, 1986, pp. 89-95. doi:10.1111/j.1469-8137.1986.tb00636.x

[4] K. Isobe, H. Sugimura, T. Maeshima and R. Ishii, "Distribution of Arbuscular Mycorrhizal Fungi in Upland Field Soil of Japan 2. Spore Density of Arbusclar Mycorrhizal Fungi and Infection Ratio Soybean and Maize Fields," Plant Production Science, Vol. 11, No. 2, 2008, pp. 171-177. doi:10.1626/pps.11.171
[5] K. Isobe, E. Aizawa, Y. Iguchi and R. Ishii, "Distribution of Arbuscular Mycorrhizal Fungi in Upland Field Soil of Japan 1. Relationship between Spore Density and the Soil Environment Factor," Plant Production Science, Vol. 10, No. 1, 2007, pp. 122-128. doi:10.1626/pps.10.122

[6] I. M. van Aarle, P. A. Olsson and B. Soderstrom, "Arbuscular Mycorrhizal Fungi Respond to the Substrate $\mathrm{pH}$ of Their Extraradical Mycelium by Altered Growth and Root Colonization," New Phytologist, Vol. 155, No. 1, 2002, pp. 173-182.

doi:10.1046/j.1469-8137.2002.00439.x

[7] C. Walker and J. M. Trappe, "Names and Epithets in the Glomales and Endogonales," Mycological Research, Vol. 97, No. 3, 1993, pp. 339-344. doi:10.1016/S0953-7562(09)81132-5

[8] J. C. Dodd, C. L. Boddington, A. Rodriguez, C. Gonzalez-Chavez and I. Mansur, "Mycelium of Arbuscular Mycorrhizal Fungi (AMF) from Different Genera: Form, Function and Detection," Plant and Soil, Vol. 226, No. 2, 2000, pp. 131-151. doi:10.1023/A:1026574828169

[9] A. H. Eom, D. C. Hartnett and G. W. H. Wilson, "Host Plant Species Effects on Arbuscular Mycorrhizal Fungal Communities in Tallgrass Prairie," Oecologia, Vol. 122, No. 3, 2000, pp. 435-444. doi:10.1007/s004420050050

[10] K. Saito, Y. Suyama, S. Sato and K. Sugawara, "Defoliation Effects on the Community Structure of Arbuscular Mycorrhizal Fungi Based on 18S rDNA Sequences," Mycorrhiza, Vol. 14, No. 6, 2004, pp. 363-373. doi:10.1007/s00572-003-0286-x

[11] D. C. Hartnett and G. W. T. Wilson, "Mycorrhizae Influence Plant Community Structure and Diversity in Tallgrass Prairie," Ecology, Vol. 80, No. 4, 1999, pp. 11871195.

doi:10.1890/0012-9658(1999)080[1187:MIPCSA]2.0.CO :2

[12] R. Husband, E. A. Herre, S. L. Turner, R. Gallery and P. W. Young, "Molecular Diversity of Arbuscular Mycorrhizal Fungi and Patterns of Host Association over Time and Space in a Tropical Forest," Molecular Ecology, Vol. 11, 2002, pp. 2669-2678.

[13] M. van der Heijden, J. N. Klironomos, M. Ursic, P. Moutoglis, E. R. Streitwolf, T. Boller, A. Weimken and I. R. Sanders, "Mycorrhizal Fungal Diversity Determines Plant Biodiversity, Ecosystem Variability and Productivity," Nature, Vol. 396, 1998, pp. 69-72. doi:10.1038/23932

[14] N. N. Bhadalung, A. Suwanarit, B. Dell, O. Nopamornbodi, A. Thamchaipenet and J. Rungchuang, "Effects of 
Long-Term NP-Fertilization on Abundance and Diversity of Arbuscular Mycorrhizal Fungi under a Maize Cropping System," Plant and Soil, Vol. 270, No. 1, 2005, pp. 371-382. doi:10.1007/s11104-004-1829-4

[15] E. Sieverding, "Vesicular-Arbuscular Mycorrhizae Management in Tropical Agrosystems," Deutsche Gesellschaft fur Technische Zusammenarbei (GTZ) GmbH, Eschboran, 1991, p. 371.

[16] J. P. Clapp, T. Helgason, T. J. Daniell and J. P. W. Young, "Genetic Studies of the Structure and Diversity of Arbuscular Mycorrhizal Fungal Communities," In: M. G. A. van der Heijden and I. R. Sanders, Eds., Mycorrhizal Ecology, Springer, Heidelberg, 2002, pp. 201-224.

[17] I. Sanders, J. P. Clapp and A. Wiemken, "The Genetic Diversity of Arbuscular Mycorrhizal Fungi in Natural Ecosystems - A Key to Understanding the Ecology and Functioning of the Mycorrhizal Symbiosis," New Phytologist, Vol. 133, No. 1, 1996, pp. 123-134. doi:10.1111/j.1469-8137.1996.tb04348.x

[18] N. Alkan, V. Gadkar, O. Yarden and Y. Kapulnik, "Analysis of Quantitative Interactions between Two Species of Arbuscular Mycorrhizal Fungi, Glomus mosseae and $G$. intraradices, by Real Time PCR," Applied and Environmental Microbiology, Vol. 72, No. 6, 2006, pp. 41924199. doi:10.1128/AEM.02889-05

[19] Z. Liang, R. A. Drijber, D. J. Lee, I. M. Dwiekat, S. D. Harris and D. A. Wedin, "A DGGE-Cloning Method to Characterize Arbuscular Mycorrhizal Community Structure in Soil," Soil Biology \& Biochemistry, Vol. 40, No. 4, 2008, pp. 956-966. doi:10.1016/j.soilbio.2007.11.016

[20] A. Porras-Alfaro, H. Herrera, D. O. Natvig and R. L. Sinsabaugh, "Effect of Long-Term Nitrogen Fertilization on Mycorrhizal Fungi Associated with a Dominant Grass in a Semiarid Grassland," Plant and Soil, Vol. 296, No. 1-2, 2007, pp. 65-75. doi:10.1007/s11104-007-9290-9

[21] C. Renker, V. Blanke and F. Buscot, "Diversity of Arbuscular Mycorrhizal Fungi in Grassland Spontaneously Developed on Area Polluted by a Fertilizer Plant," Environmental Pollution, Vol. 135, No. 2, 2005, pp. 255-266. doi:10.1016/j.envpol.2004.11.002

[22] J. C. Santos, R. D. Finlay and A. Tehler, "Molecular Analysis of Arbuscular Mycorrhizal Fungi Colonizing a Seminatural Grassland along a Fertilization Gradient," New Phytologist, Vol. 172, No. 1, 2006, pp. 159-168. doi:10.1111/j.1469-8137.2006.01799.x

[23] J. Panwar and J. C. Tarafdar, "Arbuscular Mycorrhizal Fungal Dynamics under Mitragyna parvifolia (Roxb.) Korth. in Thar Desert," Applied Soil Ecology, Vol. 34, No. 2-3, 2006, pp. 200-208. doi:10.1016/j.apsoil.2006.02.001

[24] M. M. Alguacil, E. Lumini, A. Roldan, J. R. SalinasGarcia, P. Bonfante and V. Bianciotto, "The Impact of Tillage Practices on Arbuscular Mycorrhizal Fungal Diversity in Subtropical Crops," Ecological Applications, Vol. 18, No. 2, 2008, pp. 527-536. doi:10.1890/07-0521.1

[25] J. Jansa, A. Mozafar, T. Anken, R. Ruh, I. Sanders and E. Frossard, "Diversity and Structure of AMF Communities as Affected by Tillage in a Temperate Soil," Mycorrhiza, Vol. 12, No. 5, 2002, pp. 225-234.

doi:10.1007/s00572-002-0163-Z

[26] T. P. McGonigle and M. H. Miller, "Mycorrhizae, Phosphorus Absorption, and Yield of Maize in Response to Tillage Soil," Science Society of America Journal, Vol. 60, No. 6, 1996, pp. 1856-1861. doi:10.2136/sssaj1996.03615995006000060034x

[27] M. Giovannetti and B. Mosse, "An Evaluation of Techniques for Measuring Vesicular-Arbuscular Mycorrhizal Infection in Roots," New Phytologist, Vol. 84, No. 3, 1980, pp. 679-684. doi:10.1111/j.1469-8137.1980.tb04556.x

[28] A. Gollotte, D. van Tuinen and D. Atkinson, "Diversity of Arbuscular Mycorrhizal Fungi Colonising Roots of the Grass Species Agrostis capillaris and Lolium perenne in Field Experiment," Mycorrhiza, Vol. 14, No. 2, 2004, pp. 111-117. doi:10.1007/s00572-003-0244-7

[29] S. Trouvelot, D. van Tuinen, M. Hijri and V. GianinazziPearson, "Visualization of Ribosomal DNA Loci in Spore Interphasic Nuclei of Glomalean Fungi by Fluorescence in Situ Hybridization," Mycorrhiza, Vol. 8, No. 4, 1999, pp. 203-206. doi:10.1007/s005720050235

[30] B. Y. Wu, T. Hogetsu, K. Isobe and R. Ishii, "Community Structure of Arbuscular Mycorrhizal Fungi in a Primary Successional Volcanic Desert on the Southeast Slope of Mount Fuji," Mycorrhiza, Vol. 17, No. 6, 2007, pp. 495-506. doi:10.1007/s00572-007-0114-9

[31] D. L. Mummey and M. C. Rillig, "Evaluation of LSU rRNA-Gene PCR Primers for Analysis of Arbuscular Mycorrhizal Fungal Communities via Terminal Restriction Fragment Length Polymorphism Analysis," Journal of Microbiological Methods, Vol. 70, No. 1, 2007, pp. 200-204. doi:10.1016/j.mimet.2007.04.002

[32] K. Tamura, J. Dudley, N. Nei and S. Kumar, "MEGA4: Molecular Evolutionary Genetics Analysis (MEGA) Software Version 4.0," Molecular Biology and Evolution, Vol. 24, No. 8, 2007, pp. 1596-1599. doi:10.1093/molbev/msm092

[33] M. Franke-Snyder, D. D. Douds, L. Galvez, J. G. Phillips, P. Wagoner, L. Drinkwater and J. B. Morton, "Diversity of Communities of Arbuscular Mycorrhizal (AM) Fungi Present in Conventional versus Low-Input Agricultural Sites in Eastern Pennsylvania, USA," Applied Soil Ecology, Vol. 16, No. 1, 2001, pp. 35-48. doi:10.1016/S0929-1393(00)00100-1

[34] T. Helgason, T. J. Daniell, R. Husband, A. H. Fitter and J. P. W. Young, "Ploughing Up the Wood-Wide Web?" Nature, Vol. 394, 1998, p. 431. doi:10.1038/28764

[35] J. Jansa, A. Mozafar, G. Kuhn, T. Anken, R. Ruh, I. R. Sanders and E. Frossard, "Soil Tillage Affects the Community Structure of Mycorrhizal Fungi in Maize Roots," Ecological Applications, Vol. 13, No. 4, 2003, pp. 1164 1176. doi:10.1890/1051-0761(2003)13[1164:STATCS]2.0.CO; 2

[36] F. Oehl, E. Sieverding, K. Ineichen, P. Mäder, T. Boller 
and A. Wiemken, "Impact of Land Use Intensity on the Species Diversity of Arbuscular Mycorrhizal Fungi in Agroecosystems of Central Europe," Applied and Environmental Microbiology, Vol. 69, No. 5, 2003, pp. 28162824.

[37] L. Ho, "Vesicular Arbuscular Mycorrhizae of Halophytic Grasses in the Alvard Desert of Oregon," Northwest Science, Vol. 61, No. 3, 1987, pp. 148-151.

[38] J. C. Tarafdar and P. Kumar, "The Role of Vesicular Arbuscular Mycorrhizal Fungi on Crop, Tree and Grasses Grown in an Arid Environment," Journal of Arid Environments, Vol. 34, No. 2, 1996, pp. 97-203. doi:10.1006/jare.1996.0101

[39] A. Al-Raddad, "Distribution of Different Glomus Species in Rain Fed Areas in Jordan," Dirasat, Vol. 20, 1993, pp. 165-182.

[40] N. Mathimaran, R. Ruh, P. Vullioud, E. Frossard and J. Jansaet, "Glomus intraradices Dominates Arbuscular Mycorrhizal Communities in a Heavy Textured Agricul- tural Soil," Mycorrhiza, Vol. 16, No. 1, 2005, pp. 61-66. doi:10.1007/s00572-005-0014-9

[41] Y. Lekberg, R. T. Koide, J. R. Rohr, L. Aldrich-Wolfe and J. B. Morton, "Role of Niche Restrictions and Dispersal in the Composition of Arbuscular Mycorrhizal Fungal Communities," Journal of Ecology, Vol. 95, No. 1, 2007, pp. 95-105. doi:10.1111/j.1365-2745.2006.01193.x

[42] N. C. Schenck and G. S. Smith, "Responses of Six Species of Vesicular-Arbuscular Mycorrhizal Fungi and Their Effects on Soybean at Four Soil Temperatures," New Phytologist, Vol. 92, No. 2, 1982, pp. 193-201. doi:10.1111/j.1469-8137.1982.tb03376.x

[43] V. Chifflot, D. Rivest, A. Olivier, A. Cogliastro and D. Khasa, "Molecular Analysis of Arbuscular Mycorrhizal Community Structure and Spores Distribution in TreeBased Intercropping and Forest Systems," Agriculture, Ecosystems \& Environment, Vol. 131, No. 1-2, 2009, pp. 32-39. doi:10.1016/j.agee.2008.11.010 